\title{
KAZUISZTIKÁK
}

A Pécsi Tudományegyetem Klinikai Központ, Gyermekklinika, Gyermeksebészeti Osztály ${ }^{1}$ és a Péterfy

Sándor Utcai Kórház-Rendelöintézet és Baleseti Központ, Gyermek-traumatológiai Osztály² közleménye

\section{Az olecranon és a radius fej egyidejú nagy elmozdulással járó törésének kezelése gyermekkorban}

\author{
DR. JÓZSA GERGÖ${ }^{1}$, DR. JUHÁSZZ ZSOLT ${ }^{1}$, DR. KASSAI TAMÁS²
}

\section{ÖSSZEFOGLALÁS}

A radius fej és az olecranon törés viszonylag ritka törés gyermekkorban, az összes könyöktáji törések közel 5-5\%-át teszik ki. Az esetek jelentős részében elmozdulás nélküli, vagy minimális elmozdulással járó törések jönnek létre. A szerzők két esetet mutatnak be, egyidejúleg kialakuló radius fej és olecranon törés ellátásáról. Az olecranon törés ellátása nyílt feltárásból történt, tűződrótos ostesynthesis cerclage dróttal, illetve PDS feszítő hurokkal kiegészítve. A radius fej törés repozíciója fedett, illetve percutan módszerrel, míg a törés stabilizálása aszcendáló intramedullaris elasztikus szeggel történt. A mútétet követően az érintett végtagra derékszögű felső végtagi gipszsín került felhelyezésre. A 3. héten a gipszsín eltávolításra került. A primer rekonstrukciós mútétet követően 9 héttel a fémanyagok eltávolítása is megtörtént. A szerzők két különböző típusú, egyidejű törés eltérő, jól kombinálható ellátását mutatják be.

\section{Kulcsszavak: $\quad$ Dróttüzés; Gyermekkor; Radiustörés; Töréskezelés; Intramedullaris rögzítés;}

G. Józsa, Zs. Juhász, T. Kassai: Treatment of the dislocated simultaneous olecranon and radial head fracture in children

Radial head and olecranon fractures in children are rare, representing $5-5 \%$ of all elbow pediatric fractures. In most cases, these fractures are minimally displaced or nondisplaced. The authors present two cases about the treatment of concomitant radial head and olecranon fracture. An open anatomic reduction and internal fixation was performed in both cases of ulna fracture with $\mathrm{K}$-wires and wire or PDS loop. The reposition of the radial head was achieved by closed reduction or via percutaneous method, while fixation of the fracture was performed by ascending elastic intramedullary nailing technique. After the surgery, the affected upper limb was stabilized with rectangular cast. Following 3 weeks of immobilization the cast was removed, and 9 weeks after the primary reconstruction the metals were taken out. The authors report distinct, good combinable surgical treatments of two cases of simultaneous radial head and olecranon fracture.

Key words: $\quad$ Bone wires; Child; Fracture fixation - Methods; Radius fractures - Surgery; 


\section{BEVEZETÉS}

A könyöktáji törések gyermekkorban viszonylag gyakoriak, a radius fej törés a könyöktáji törések körülbelül 5\%-át teszik ki (7). A radius fej törések közel feléhez más könyöktáji sérülés is társul (6). Nyújtott könyökízületet érő direkt trauma hatására egyidejű olecranon és radius fej törés jöhet létre. A radius fej törés kezelése függ a kitört darab elmozdulásának mértékétől és szöglettörésétől, ezek alapján a törés klasszifikációját Judet állította fel (8). A legtöbb esetben elmozdulás nélküli vagy minimális elmozdulással $\left(<15^{\circ}\right)$ járó törés alakul ki, amely konzervatív kezeléssel jó funkcionális eredménnyel gyógyítható $(4,10)$. A $30^{\circ}$-nál nagyobb elmozdulással járó radius fej törés kezelése operatív. A kitört darab visszahelyezhető percutan technikával tűződróttal $(3,11)$, minimál invazív módon, aszcendáló intarmedullaris elasztikus szeggel $(1,9,11)$, fedett vagy percutan módon végzett repozíció sikertelensége esetén nyílt feltárás során tűződróttal vagy felszívódó implantátumokkal (2). Az olecranon törés az 5 és 10 év közötti fiú korcsoportban a leggyakoribb, 20\%-ban társul egyéb könyöktáji sérüléssel (5). Az elmozdulás nélküli törések konzervatív, míg az elmozdulással járó olecranon törések kezelése operatív. A nyílt feltárás mellett történő repozíció, illetve a tűződrótokkal történő fixálás húzóhurokkal kiegészítve a jól bevált módszer. Az irodalomban kevés információ, dokumentált eset található az egyidejü olecranon és radius fej törés incidenciájáról és kezeléséről. A szerzők a törés kezelését mutatják be két gyermek esete kapcsán.

\section{ESETISMERTETÉS}

\section{I.}

Az ötéves fiúgyermek játék közben nyújtott kézzel bal könyökére esett. Ezt követően a fájdalom miatt nem tudta mozgatni a könyökét. A fizikális vizsgálat sorản a könyökízület felett dorsalisan, illetve radialisan jelentős duzzanatot és fájdalmat észleltünk. A könyökízület mozgásait a kifejezett fájdalom miatt nem lehetett vizsgálni. A bal felső végtag beidegzése és a keringése megtartott volt. A primer röntgenvizsgálat olecranon, illetve Judet III-as típusú radius fej törést mutatott (1. ábra). Általános érzéstelenítésben, antibiotikus védelemben a radius fej törését percutan technikával tűződróttal reponáltuk és intramedullaris titán elasztikus szeggel (TEN) stabilizáltuk. Az olecranon törést nyílt feltárásból reponáltuk és tűződrótos osteosynthesist végeztünk PDS feszítő hurokkal kiegészítve (2. ábra). A bal felső végtagra „U” sínnel kiegészített derékszögú gipszsínt helyeztünk. Három hét immobilizálást követően a gipszet eltávolítottuk, majd gyógytornát kezdtünk az ízület bemozgatása céljából. Kilenc héttel a mútétet követően a törés átépülését észleltük, így a fémanyagokat narkózisban eltávolítottuk. A primer mútétet követően 7 héttel a gyermek a bal könyökízületét teljes funkcióval használta.
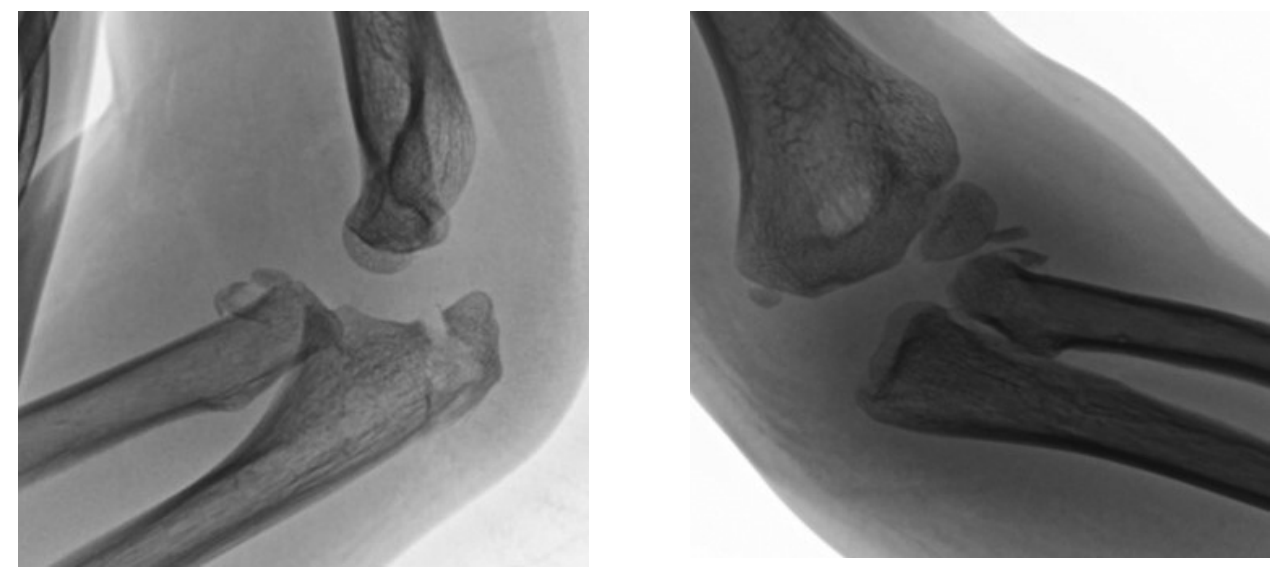

1. ábra Primer röntgenfelvétel: az olecranon törés Judet III-as típusú radius fej töréssel társul

a) Bal könyök oldalfelvétel

b) Bal könyök AP felvétel 

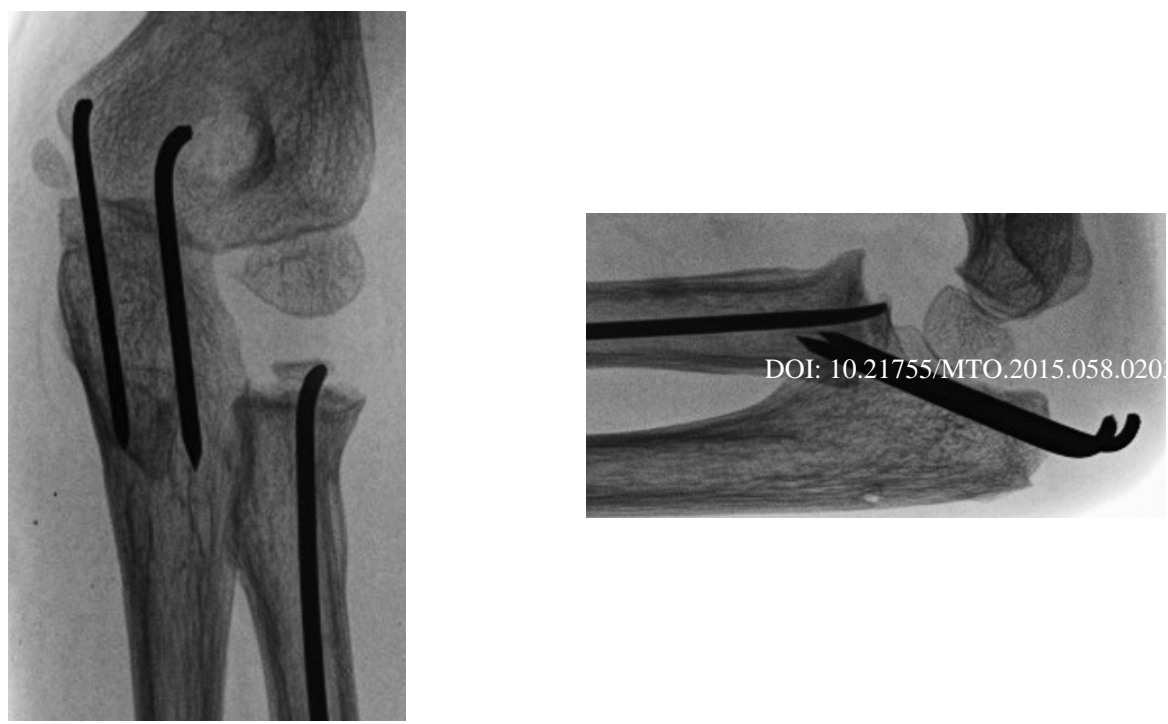

2. ábra Bal könyök röntgenfelvétel 8 héttel a mütétet követöen. A törés átépülése látható

a) Bal könyök AP felvétel

\section{II.}

Az ötéves lánygyermek lóról esett le, bal könyökét ütötte meg. Az esést követően kialakuló kifejezett duzzanat, fájdalom és mozgáskorlátozottság miatt jelentkeztek ambulanciánkon. A fizikális vizsgálat során jelentősen beszúkült mozgásterjedelmú bal könyökízületet észleltünk, dorsalisan lévő kifejezett haematomával és érzékenységgel. A bal felső végtag keringése és beidegzése rendben volt. A primer röntgenfelvétel Judet III-as típusú radius fej törést és nagy elmozdulással járó olecranon törést mutatott (3. ábra). Általános érzéstelenítésben az olecranon törést nyílt feltárás mellett reponáltuk, majd túződrótokkal stabilizáltuk, drót húzóhurokkal kiegészítve. A radius fej törését percutan reponáltuk, majd b) Bal könyök oldalfelvétel

titán elasztikus szeggel stabilizáltuk (4. ábra). A bal felső végtagot „U” sínnel kiegészített derékszögú dorsalis gipszsínnel rögzítettük. A primer ellátást követően három héttel a gipszet eltávolítottuk, ezt követően a gyermek rendszeres gyógytornakezelésben részesült, amelynek hatására a könyökízületi mozgások a 8. hétre teljes terjedelemben visszatértek. Három hónappal a mútét után a fémanyagokat narcosisban eltávolítottuk.

A két gyermek esete hasonló, az ellátás két különböző intézetben megegyező elvek és technikák szerint történt. Egy különbség azonban kiemelendő, hogy az első esetben a húzóhurok kialakítása PDS varrattal, míg a második esetben dróthurokkal történt. 

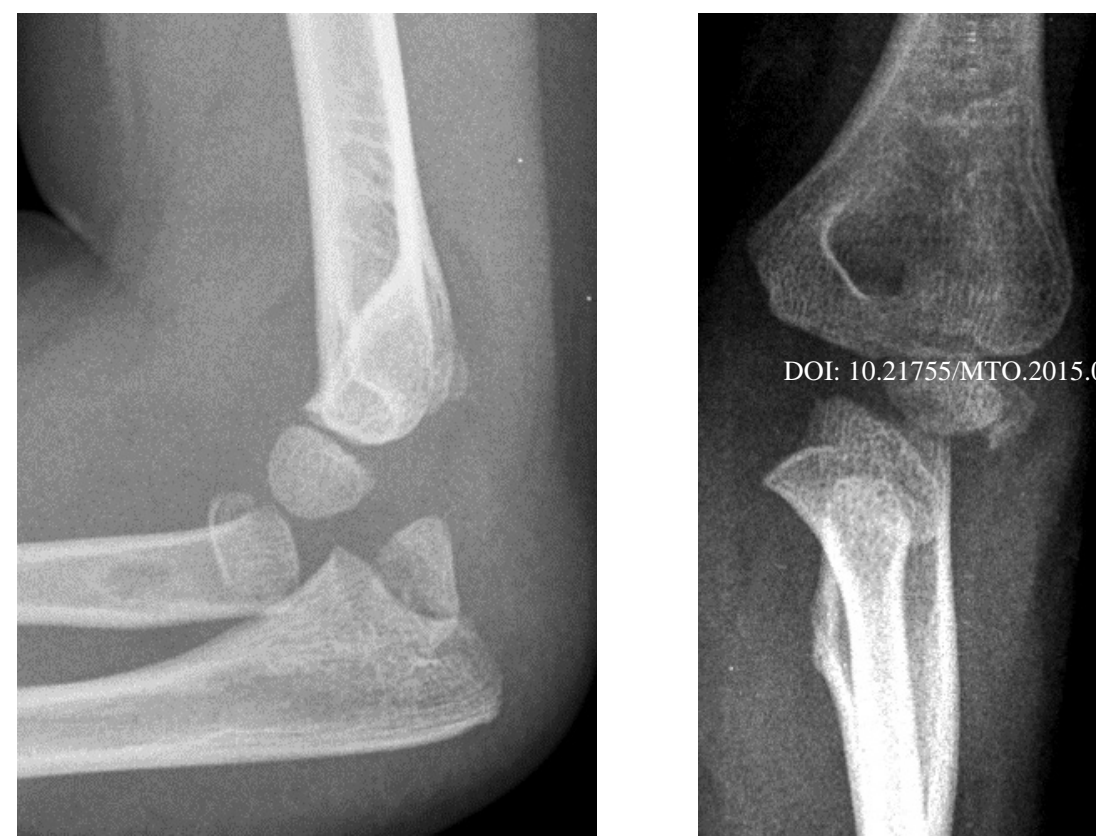

3. ábra Ventralis könyökízületi ficamhoz társuló olecranon és Judet III-as típusú radius fej törés a) Bal könyök oldalfelvétel

b) Bal könyök antero-posterior (AP) felvétel
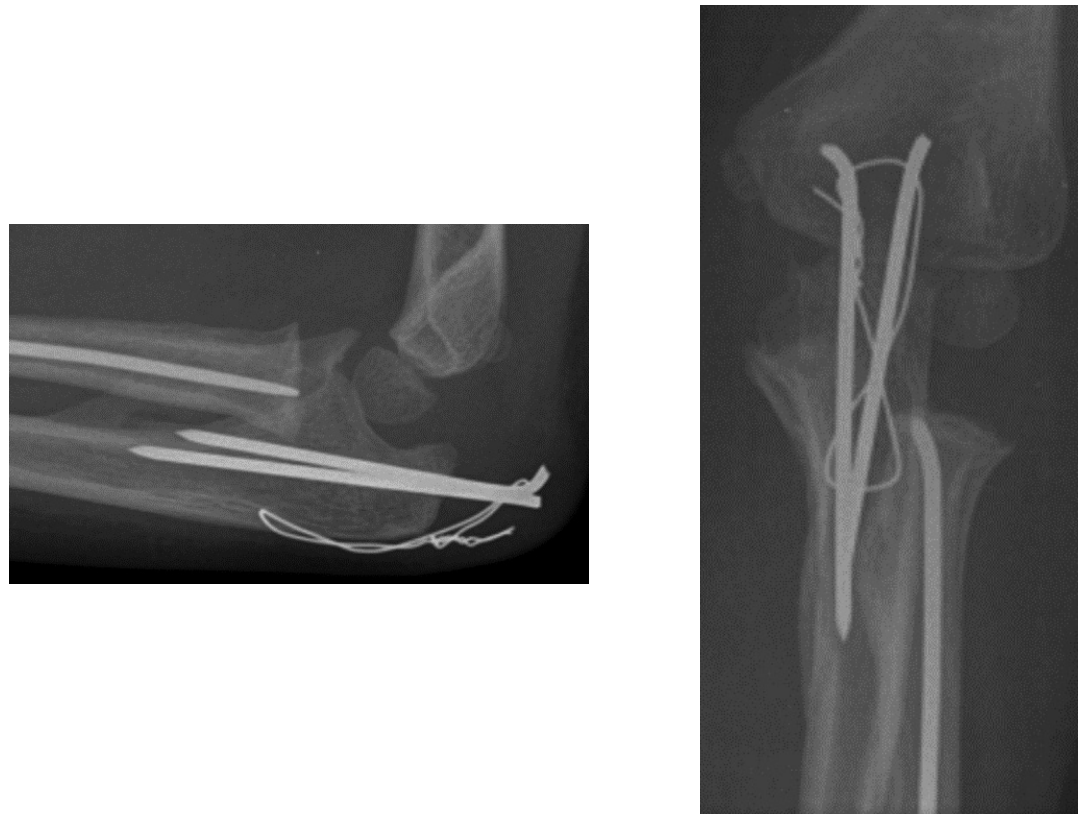

4. ábra Bal könyökízület röntgenfelvétel 9 héttel a mütétet követöen: a radius fej elasztikus szeggel, míg az olecranon húzóhurokkal kiegészített tüződrótos osteosynthesissel rögzítve
a) Bal könyök oldalfelvétel
b) Bal könyök AP felvétel 


\section{MEGBESZÉLÉS}

Mind az olecranon, mind a radius fej törés viszonylag gyakran társul egyéb könyöktáji sérülésekkel. Mindkét törés előfordulása fiúkban gyakoribb. Az egyidejú sérülés rendkívül ritka, irodalmi publikációk száma is azt mutatja, hogy igen ritka törés kombinációról van szó.

A radius fej törés kezelését Judet klaszszifikációja alapján határozhatjuk meg. Az I-II-es típusú sérülések konzervatív kezelést, míg a III-as típusú törések mútéti beavatkozást igényelnek. Több mútéti eljárás is ismert, azonban ma a leginkább elfogadott kezelés a fedett vagy percutan módszerrel történő repozíció és a törés intramedullaris elasztikus szeggel történő stabilizálása. A kis dislocatióval járó olecranon törés kezelése konzervatív módon történik, míg a nagyobb elmozdulással járó törések kezelése egyértelmúen mútéti beavatkozást igényel. A tüződrótos osteosynthesis húzóhurokkal kiegészítve a gold standard mútéti eljárás, gipszrögzítéssel kiegészítve. Együttes sérülés esetén a két módszer kombinálva alkalmazható.

A sérülést követően 10-12 héttel a gyermekek panaszmentesen, teljes funkcióval használták bal könyökízületüket. Az olecranon törések általában szövődménymentesen, tökéletesen gyógyulnak, azonbar ritkán €iöfor duló szövődményekre lehet számítani, mint az álízület, a tǔződrótok által okozott bőr irritáció (5). A radius fej törések esetében a fej növekedési zavara alakulhat ki, a csont deformálttá válhat, súlyos esetben el is halhat. Nyílt repozíciót követően 10-20\%-ban avascularis necrosis is létrejöhet (10), ezért is fontos, hogy a sérült gyermek a növekedés befejeződéséig gondozás alatt maradjon.

\section{IRODALOM}

1. Al-Aubaidi Z., Pedersen N. W., Nielsen K. D.: Radial neck fractures in children treated with the centromedullary Metaizeau technique. Injury. 2012. 43: 301-305.

2. Beaty J. H., Kasser J. R. (Eds.): Rockwood and Wilkins' fractures in children. 7. ed. Philadelphia: Lippincott Williams and Wilkins. 2010.

3. Cha S. M., Shin H. D., Kim K. C., Han S. C.: Percutaneous reduction and leverage fixation using K-wires in pediatric angulated radial neck fractures. Int. Orthop. 2012. 36: 803-809.

4. Chotel F., Vallese P., Parot R., Laville J. M., Hodgkinson I., Muller C., Berard J.: Complete dislocation of the radial head following fracture of the radial neck in children: the Jeffery type II lesion. J. Pediatr. Orthop. B. 2004. 13: 268-274.

5. Dailiana Z. H., Papatheodorou L. K., Michalitsis S. G., Varitimidis S. E.: Pediatric terrible triad elbow fracture dislocations: report of 2 cases. J. Hand Surg. Am. 2013. 38. (9):.1774-1778.

6. Dormans J. P., Rang M.: Fractures of the olecranon and radial neck in children. Orthop. Clin. North Am. 1990. 21: 257-268.

7. Falciglia F., Giordano M., Aulisa A. G., Di Lazzaro A., Gu.zzanti V.: Radial neck fractures in children: Results when open reduction is indicated. J. Pediatr. Orthop. 2014. 34: 756-762.

8. Hässle M., Mellerowicz H.: Frakturen des proximalen Radius im Wachstumsalter. Unfallchirurgie, 1991. 17: 24-33.

9. Novoth B., Fekete K., Hargitai E., Kassai T., Kõvári T., Sashegyi M.: Closed reduction and intramedullary pinning of radial neck fractures in children. J. Orthop. Traumatol. 2002. 10: 289-298.

10. Pring M. E.: Pediatric radial neck fractures: when and how to fix. J. Pediatr. Orthop. 2012. 32: S14-S21.

11. Tarallo L., Mugnai R., Fiacchi F., Capra F., Catani F.: Management of displaced radial neck fractures in children: percutaneous pinning vs. elastic stable intramedullary nailing. J. Orthop. Traumatol. 2013. 14: 291-297.

12. Ursei M., Sales de Gauzy J., Knorr J., Abid A., Darodes P., Cahuzac JP.: Surgical treatment of radial neck fractures in children by intramedullary pinning. Acta Orthop. Belg. 2006. 72: 131-137.

\section{Dr. Józsa Gergö}

PTE-KK Gyermekklinika Gyermeksebészeti Osztály

7623 Pécs, József A. u.7

dr.jozsa.gergo@gmail.com 